\title{
Nutritional Quality of Commercially Available Unbranded Cereal Snacks Consumed by School Children
}

\author{
S. Akkavva Wadakappanavar* and Nirmala B. Yenagi \\ Department of Food Science and Nutrition, Collage of Rural Home Science, University of \\ Agricultural Sciences, Dharwad- 580 005, Karnataka, India \\ *Corresponding author
}

\section{A B S T R A C T}

Snacking is considered as fourth meal of the day. Snacks are part of a healthy diet for children. School children identify snacks by quantity, cost and sensory attributes especially color and taste. The objective of the study was to evaluate the nutritional quality of unbranded cereal based snacks prepared from the bulk raw material which is obtained at lower price from wheat and other pulse milling industry. Ten unbranded cereal based

Keywords

Commercial, Unbranded, Snacks, School children.

Article Info

Accepted:

17 July 2017

Available Online:

10 September 2017 snacks such as papadi, kodbale, ghate, sevchakli, berfi, mysorepak, milkpedha, benne biscuit, ragulla were collected from the whole sale shop and analyzed the nutrient composition of snacks. The proximate composition and micro nutrient content significantly varied at $1 \%$ level $(\mathrm{p}<0.01)$ between the snacks. The moisture, protein, fat, ash and crude fiber content ranged from 1.46 to $13.38,1.24$ to $15.16,5.12$ to $26.59,0.26$ to 4.52 and 0.49 to $3.76 \mathrm{~g} / 100 \mathrm{~g}$ respectively. The calcium, iron, copper, zinc and manganese content of snacks varied from 3.31 to $13.62,69$ to $4.91,0.10$ to $0.35,0.99$ to 2.23 and 0.43 to $2.53 \mathrm{mg}$ respectively. These snacks are meeting only 0.02 to $0.11 \%, 0.21$ to $0.76 \%$ and 0.01 to $0.03 \%$ of recommended protein, calcium and iron requirement of school children for one rupee. Snacks are found to be rich in fat content and energy, contributing greater amount to the $1 / 4^{\text {th }}$ of day's requirement of 3.5 to $18.4 \%$ and 4.1 to $12 \%$ respectively. The present studies suggest that the small scale snack industries should consider the nutritional guidelines for regulation of products for children to overcome the nutritional health problems. Snacks are not providing adequate nutrients required by the school children but, they contain high fat and calorie dense. Commercial snacks can enriched with addition of composite flour or addition of skim milk powder without increasing the cost of the product.

\section{Introduction}

Snack is described as a small quantity of food eaten between meals or in place of a meal. Snacks are considered as fourth meal of the day (http://www.eatouteatwell.com/snacksare-they-your-fourth-meal). Snack food generally comprises bakery products, readyto-eat foods, chips, namkeen and other light processed foods. Snacks account for $25 \%$ of all meals consumed daily. Globalization, liberalization, mall culture and urbanization have brought about radical changes in the snacking pattern of the people across the nation, resulting into the escalating intake of processed and fast food. Snacks are part of a healthy diet for children. School age is the active and dynamic phase of physical growth 
as well as mental development of the child. The school age period is nutritionally significant because this is the prime time to build up body stores of nutrients in preparation for rapid growth of adolescence. Creating a healthy snack consumption pattern can help to provide children nutritious food throughout the day. Because children do not always eat enough meal, providing one to two snacks per day can help them get the missed nutrients/ micronutrients.

Snacking is one of the fastest growing industries. In the savory snacks, the Indian market has been forecasted the highest growth among all the other countries in the world (www.fbnews.com). Most of the commercial snacks are prepared from the raw material which is available in bulk at low price. For instant refined wheat flour is one of the major bye product of wheat milling industry, which is used widely in bakery industry, restaurants/hotels and also in preparation of children snacks. Refined wheat flour has very good functional properties in preparation several snacks because of gluten content. However this flour is devoid of micronutrients and also fibre. Similarly maize flour and peas flour are also available in bulk and widely used in snack manufacturing units. Further commercial snacks are attracted by children for color and taste with addition of additives (Dixit et al., 2010; Hussain et al., 2008). The health is being compromised at the cost of replacing nutritious balanced diets with High Fat, Sugar and Salt (HFSS) foods (Anon, 2015; Lythgoe et al., 2013).

There are 444 million children in India under the age of 18 years. This constitutes $37 \%$ of the total population in the country (http://www.cry.org/statistics-on-children). About $16 \%$ populations is under nourished and suffering from micro nutrient deficiencies. Micronutrient deficiencies impair cognitive development and lower resistance to disease in children and adults.
The school children population approximate one fifth of the total population and forms the future hope of the Nation. Health of the children is the wealth of the Nation. It is necessary to improve the dietary habits of school children by providing appropriate and wholesome mix of foods and also encourages them to avoid consumption of unhealthy snacks. Well-portioned snacks between meals can help children make a habit of grazing throughout the day, and encouraging nutritious snacks will allow them to develop healthy eating habits and helps in maintain good health. Hence, the present study was undertaken to evaluate the nutrition quality of commercial snacks prepared from blended flour of different fractions of milling industry

\section{Materials and Methods}

\section{Selection of cereal based snacks}

Unbranded cereal based snacks were recorded from 30 shops, covering 2 each shops from five villages of Hubli and Dharwad Taluks and 10 each shops from Hubli and Dharwad cities. Later ten cereal based snacks comprising five savory and five sweet snacks were selected on the basis of their availability in majority of shops situated near school premises.

\section{Collection of cereal based snacks}

Ten selected snacks were procured from one of the whole sale shops of Dharwad city, from where the snacks were distributed to retail shops. The selected snacks were chakli, sevchakli, ghate, kodbale, papadi, milk-pedha, burfi, mysorepak, benne biscuit and rasgulla (Plate 1). Most of the snacks were available without any brand name, quantity, cost, nutrition labeling and ingredients used. Brief description of these snacks is furnished in table 1. 
Nutrient composition of cereal based snacks

\section{Proximate composition}

The samples were ground into fine powder, defatted and packed in zip lock pouches and stored in a desiccator and used for analysis of proximate composition except for fat.

The moisture, protein, fat, ash and crudefiber contents were analyzed by following standard AOAC methods (AOAC, 2005) and were expressed in $\mathrm{g} / 100 \mathrm{~g}$. The gross energy values were estimated by multiplying the protein, fat and carbohydrate by their at water values of 4 , 9 and $4 \mathrm{kcal} / \mathrm{g}$ respectively.

\section{Trace elements}

The trace elements (iron, zinc, copper and manganese) were estimated by wet digestion using triacid mixture. A known aliquot of test sample was suitably diluted and micronutrients in the test sample $(\mathrm{Cu}, \mathrm{Mn}, \mathrm{Zn}$ and $\mathrm{Fe}$ ) were determined using Atomic Absorption Spectrophotometer (AOAC, 2005). Calcium was estimated by following titrimetric method. Calcium was precipitated as oxalate and titrated against standard potassium permanganate (AOAC, 2005).

\section{Statistical analysis}

All chemical analyses was performed in triplicates $(n=3)$ and the data was presented as mean \pm SD. To know the difference between the proximate composition and mineral composition of cereal based snacks, statistical analysis one way ANOVA was carried out using SPSS (Statistical Packages for Social Sciences) software version 16.0.

\section{Results and Discussion}

The proximate composition of unbranded cereal based snacks is presented in table 2 .
The composition significantly varied at $1 \%$ level $(p<0.01)$ between the snacks. The moisture, protein, fat, ash and crude fiber content ranged from 1.46 to $13.38,1.24$ to $15.16,5.12$ to $26.59,0.26$ to 4.52 and 0.49 to $3.76 \mathrm{~g} / 100 \mathrm{~g}$ respectively. The wide variation in the proximate composition of cereal snacks may be attributed to variation in the ingredients and their quantity used in preparation.

The significant variation in moisture content of commercial snacks may be attributed to method of preparation (Fellows, 2000). Among the snacks, the highest moisture content of $13.38 \mathrm{~g}$ was observed in rasgulla and the lowest in burfi (1.46g). Cooking and soaking of rasgulla in sugar syrup may be responsible for high moisture content, whereas burfi is prepared with concentrated sugar syrup. Uma et al., 1997 reported slightly higher moisture content $(18.42 \mathrm{~g})$ in the commercially available dry rasgulla.

The highest protein content was observed in milk pedha $(15.16 \mathrm{~g})$ followed by mysorepak $(9.17 \mathrm{~g})$ and kodbale $(8.60 \mathrm{~g})$ and lowest was in rasgulla $(1.24 \mathrm{~g})$. The highest ash content was observed in papadi $(4.52 \mathrm{~g})$ followed by sevchakli $(3.93 \mathrm{~g})$ and ghate $(3.46 \mathrm{~g})$ and lowest was in rasgulla $(0.26 \mathrm{~g})$. The highest crude fiber content was observed in papadi $(3.76 \mathrm{~g})$ followed by burfi $(3.21 \mathrm{~g})$ and ghate $(1.92 \mathrm{~g})$ and least was observed in benne biscuit $(0.49 \mathrm{~g})$.

As there was no information regarding the ingredients used in preparation of commercial snacks, it was difficult to predict the reasons for variation in the nutrient content of snacks. The oral communication with the whole seller and one of the owners of the home based snack industries, it was found that maize flour, refined wheat flour and peas flour were available in bulk at cheaper price in the market and also various blends of these flours were readily available in bulk for preparation 
of varieties of snacks. The nutritional profile of these flours was not available.

The variation in protein, ash and crude fibre in snacks might be due addition ingredients like skim milk powder in milk peda and use of blended of flours of peas and maize flour with refined wheat flour in snacks such as papadi, sevchakli, ghate, kodbale and burfi.

The carbohydrate content in rasgulla was found highest $(79.43 \mathrm{~g})$ followed by burfi $(78.36 \mathrm{~g})$, sevchakli $(71.29 \mathrm{~g})$ and lowest was in milk pedha $(56.40 \mathrm{~g})$. The energy content among the commercial snacks varied from 515 to $369 \mathrm{Kcal}$. Highest was observed in milk pedha and lowest in rasgulla. The variation in carbohydrate and energy content of snacks may be due to inclusion of more sugar or fat in commercial snacks. Micronutrient content of cereal based snacks is presented in table 3 . The calcium content of snacks varied from 3.31 to $13.62 \mathrm{mg}$. Highest calcium content was found in milk pedha and lowest in benne biscuit. Iron content was ranged from0.69 to $4.91 \mathrm{mg}$.

Highest was in burfi and lowest in papadi. Copper content was ranged from 0.10 to $0.35 \mathrm{mg}$. Highest was in sevchakli and lowest in milk pedha and rasgulla. Zinc content was ranged from 0.99 to $2.23 \mathrm{mg}$. Highest was in sevchakli and lowest was in burfi and rasgulla. Manganese was ranged from 0.43 to $2.53 \mathrm{mg}$. Highest was in benne biscuit and lowest in mysorepak.

Table.1 Description of commercial unbranded snacks

\begin{tabular}{|l|l|l|}
\hline \multicolumn{1}{|c|}{ S. No. } & \multicolumn{1}{|c|}{ Snacks } & \multicolumn{1}{c|}{ Description } \\
\hline 1. & Papadi & $\begin{array}{l}\text { Extruded savory snack, hollow, long and cylindrical in shape, yellow in color and it is } \\
\text { prepared from blends of stream flours. }\end{array}$ \\
\hline 2. & Kodbale & $\begin{array}{l}\text { Deep fried snack in the form of rings, golden yellow in color. It is prepared with blend of } \\
\text { flours. }\end{array}$ \\
\hline 3. & Ghate & $\begin{array}{l}\text { Crunchy and spicy deep fried strands shaped into cylinders, brick red in colour. It is } \\
\text { prepared with blend of flours. }\end{array}$ \\
\hline 4. & Sevchakli & $\begin{array}{l}\text { Sev is a crispy, very thin and coiled in spiral shape chakli resembles like noodle; yellow in } \\
\text { colour. Prepared with blend of flours. }\end{array}$ \\
\hline 5. & Chakli & $\begin{array}{l}\text { A savory snack, spiral shaped, with a spiked surface; yellow in color. Prepared with wide } \\
\text { various mixture of flours. Prepared with blend of flours. }\end{array}$ \\
\hline 6. & Burfi & A sweet snack square in shape, cream in color. Prepared with blend of flours. \\
\hline 7. & Mysorepak & A sweet snack, rectangle in shape, Creamish brown in color. Prepared with blend of flours. \\
\hline 8. & Milk pedha & $\begin{array}{l}\text { A sweet snack, rectangle in shape, cream in color, prepared with stream of wheat flour and } \\
\text { skimmed milk powder. }\end{array}$ \\
\hline 9. & Benne biscuit & $\begin{array}{l}\text { A bakery snack item, round in shape, brown in color. Prepared with stream of refined } \\
\text { wheat flour. }\end{array}$ \\
\hline 10. & Rasgulla & $\begin{array}{l}\text { A sweet snack round in shape and red in color. Prepared with refined wheat flour. Red } \\
\text { colour additive is added, dipped in sugar syrup and sold in the market as a dry rasgulla. }\end{array}$ \\
\hline
\end{tabular}


Table.2 Proximate composition of cereal based snacks (g/100g)

\begin{tabular}{|c|c|c|c|c|c|c|c|c|}
\hline Sl. No & Snacks & Moisture & Protein & Fat & Ash & Crude fiber & CHO & Energy (Kcal) \\
\hline 1. & Papadi & $4.49 \pm 0.15^{\mathrm{e}}$ & $8.54 \pm 0.01 \mathrm{c}$ & $13.56 \pm 1.23^{\mathrm{e}}$ & $4.52 \pm 0.06^{\mathrm{a}}$ & $3.76 \pm 0.18^{\mathrm{a}}$ & $65.13 \pm 1.57^{\mathrm{de}}$ & $416 \pm 5.03^{g}$ \\
\hline 2. & Kodbale & $2.54 \pm 0.26^{\mathrm{g}}$ & $8.60 \pm 0.02 \mathrm{c}$ & $19.27 \pm 0.62^{d}$ & $2.68 \pm 0.04^{\mathrm{d}}$ & $1.16 \pm 0.03^{\mathrm{d}}$ & $65.76 \pm 0.34^{d}$ & $470 \pm 4.04^{\mathrm{d}}$ \\
\hline 3. & Ghate & $6.65 \pm 0.03^{c}$ & $7.78 \pm 0.07 d$ & $16.30 \pm 0.17^{\mathrm{e}}$ & $3.46 \pm 0.04^{\mathrm{c}}$ & $1.92 \pm 0.04^{\mathrm{c}}$ & $63.89 \pm 0.10 \mathrm{e}$ & $433 \pm 1.00^{f}$ \\
\hline 4. & Sevchakli & $8.42 \pm 0.10^{b}$ & $6.36 \pm 0.06 f$ & $8.16 \pm 1.27^{\mathrm{g}}$ & $3.93 \pm 0.04^{b}$ & $1.84 \pm 0.02^{\mathrm{c}}$ & $71.29 \pm 1.27^{\mathrm{b}}$ & $384 \pm 6.43^{h}$ \\
\hline 5. & Chakli & $4.41 \pm 0.11^{\mathrm{e}}$ & $2.39 \pm 0.12 \mathrm{~h}$ & $23.87 \pm 0.97^{b}$ & $2.47 \pm 0.02^{\mathrm{e}}$ & $1.85 \pm 0.02^{\mathrm{c}}$ & $65.02 \pm 0.82^{\mathrm{de}}$ & $484 \pm 5.51^{\mathrm{c}}$ \\
\hline 6. & Burfi & $1.46 \pm 0.01^{\mathrm{h}}$ & $5.50 \pm 0.06 \mathrm{~g}$ & $11.12 \pm 0.70^{f}$ & $0.35 \pm 0.02^{\mathrm{h}}$ & $3.21 \pm 0.01^{b}$ & $78.36 \pm 0.70 \mathrm{a}$ & $435 \pm 3.79^{f}$ \\
\hline 7. & Mysorepak & $3.92 \pm 0.05^{\mathrm{f}}$ & $9.17 \pm 0.08 b$ & $15.67 \pm 0.03^{\mathrm{e}}$ & $0.41 \pm 0.02^{\mathrm{h}}$ & $1.25 \pm 0.02^{\mathrm{d}}$ & $69.59 \pm 0.03 c$ & $456 \pm 0.00^{\mathrm{e}}$ \\
\hline 8. & Milk pedha & $2.58 \pm 0.05^{\mathrm{g}}$ & $15.16 \pm 0.00 \mathrm{a}$ & $25.39 \pm 0.78^{\mathrm{a}}$ & $0.48 \pm 0.02^{\mathrm{f}}$ & $0.00 \pm 0.00 \mathrm{f}$ & $56.40 \pm 0.74^{\mathrm{g}}$ & $515 \pm 4.16^{\mathrm{a}}$ \\
\hline 9. & Benne biscuit & $5.56 \pm 0.10^{\mathrm{d}}$ & $7.50 \pm 0.16 \mathrm{e}$ & $26.59 \pm 0.23^{\mathrm{a}}$ & $0.30 \pm 0.01^{i}$ & $0.49 \pm 0.01^{\mathrm{e}}$ & $59.56 \pm 0.50 \mathrm{f}$ & $507 \pm 0.58^{b}$ \\
\hline 10. & Rasgulla & $13.38 \pm 0.07^{\mathrm{a}}$ & $1.24 \pm 0.00 \mathrm{i}$ & $5.12 \pm 0.10^{\mathrm{h}}$ & $0.26 \pm 0.01^{\mathrm{i}}$ & $0.56 \pm 0.01^{\mathrm{e}}$ & $79.43 \pm 0.18^{\mathrm{a}}$ & $369 \pm 0.00^{i}$ \\
\hline \multicolumn{2}{|l|}{ S.Em \pm} & 0.07 & 0.05 & 0.43 & 0.02 & 0.04 & 0.45 & 2.21 \\
\hline \multicolumn{2}{|c|}{$\begin{array}{l}\text { C.D.(0.01) } \\
\end{array}$} & $0.20 * * *$ & $0.13 * * *$ & $1.28 * * *$ & $0.05 * * *$ & $0.10 * * *$ & $1.34 * * *$ & $6.52 * * *$ \\
\hline \multicolumn{2}{|l|}{ F-value } & 2766.58 & 7204.64 & 283.40 & 8477.68 & 1143.06 & 265.91 & 490.14 \\
\hline
\end{tabular}

Table.3 Micronutrient content of cereal based snacks (mg/100g)

\begin{tabular}{|c|c|c|c|c|c|c|}
\hline Sl. No & Snacks & Calcium & Iron & Copper & Zinc & Manganese \\
\hline 1. & Papadi & $4.00 \pm 0.00^{\mathrm{de}}$ & $0.69 \pm 0.06^{\mathrm{f}}$ & $0.25 \pm 0.01^{a b c}$ & $1.23 \pm 0.08^{\mathrm{de}}$ & $1.31 \pm 0.60^{\mathrm{a}}$ \\
\hline 2. & Kodbale & $4.10 \pm 0.14^{\mathrm{de}}$ & $1.46 \pm 0.04^{\mathrm{e}}$ & $0.24 \pm 0.09^{\mathrm{abc}}$ & $1.23 \pm 0.08^{\mathrm{de}}$ & $2.51 \pm 2.48^{\mathrm{a}}$ \\
\hline 3. & Ghate & $3.50 \pm 0.71^{\mathrm{ef}}$ & $2.26 \pm 0.38^{\mathrm{cd}}$ & $0.33 \pm 0.14^{\mathrm{ab}}$ & $1.95 \pm 0.16^{b}$ & $1.34 \pm 0.52^{a}$ \\
\hline 4. & Sevchakli & $4.91 \pm 0.15^{\mathrm{bc}}$ & $2.05 \pm 0.03^{\mathrm{d}}$ & $0.35 \pm 0.04^{\mathrm{a}}$ & $2.23 \pm 0.04^{\mathrm{a}}$ & $1.18 \pm 0.21^{\mathrm{a}}$ \\
\hline 5. & Chakli & $4.41 \pm 0.29^{\mathrm{cd}}$ & $2.18 \pm 0.01^{\mathrm{cd}}$ & $0.16 \pm 0.00^{c}$ & $1.50 \pm 0.04^{\mathrm{c}}$ & $1.36 \pm 0.57^{\mathrm{a}}$ \\
\hline 6. & Burfi & $5.11 \pm 0.14^{b}$ & $4.91 \pm 0.01^{\mathrm{a}}$ & $0.21 \pm 0.08^{a b c}$ & $0.99 \pm 0.01^{\mathrm{f}}$ & $1.76 \pm 0.13^{\mathrm{a}}$ \\
\hline 7. & Mysorepak & $4.50 \pm 0.14^{\mathrm{bcd}}$ & $2.33 \pm 0.04^{\mathrm{cd}}$ & $0.19 \pm 0.00^{\mathrm{bc}}$ & $1.10 \pm 0.00^{\mathrm{ef}}$ & $0.43 \pm 0.01^{\mathrm{a}}$ \\
\hline 8. & Milk pedha & $13.62 \pm 0.28^{\mathrm{a}}$ & $4.11 \pm 0.01^{b}$ & $0.10 \pm 0.02^{\mathrm{c}}$ & $1.31 \pm 0.11^{\mathrm{d}}$ & $0.50 \pm 0.01^{\mathrm{a}}$ \\
\hline 9. & Benne biscuit & $3.31 \pm 0.15^{\mathrm{f}}$ & $4.04 \pm 0.02^{b}$ & $0.22 \pm 0.01^{\mathrm{abc}}$ & $1.11 \pm 0.01^{\mathrm{ef}}$ & $2.53 \pm 1.12^{\mathrm{a}}$ \\
\hline 10. & Rasgulla & $4.51 \pm 0.14^{\mathrm{bcd}}$ & $2.36 \pm 0.07^{\mathrm{c}}$ & $0.10 \pm 0.01^{\mathrm{c}}$ & $0.99 \pm 0.09^{f}$ & $0.76 \pm 0.20^{\mathrm{a}}$ \\
\hline \multicolumn{2}{|l|}{ S.Em \pm} & 0.2 & 0.09 & 0.04 & 0.05 & 0.65 \\
\hline \multicolumn{2}{|l|}{ C.D. } & $0.63 * *$ & $0.28 * *$ & $0.14 *$ & $0.17 * *$ & $2.05 \mathrm{NS}$ \\
\hline \multicolumn{2}{|l|}{ F-value } & 230.41 & 230.98 & 3.71 & 57.78 & 1.28 \\
\hline
\end{tabular}

** Significant @ 1\% level, * Significant @ 5\% level, NS-Non Significant 
Table.4 Per rupee availability of cereal based snacks for selected nutrients

\begin{tabular}{|c|c|c|c|c|c|c|c|c|c|c|c|}
\hline \multirow{2}{*}{ SI. No } & \multirow{2}{*}{ Snacks } & \multirow{2}{*}{ Quantity } & \multirow{2}{*}{$\begin{array}{l}\text { Cost } \\
\text { (Rs.) }\end{array}$} & \multirow{2}{*}{$\begin{array}{l}\text { Weight } \\
\text { (g/rupee) }\end{array}$} & \multirow{2}{*}{$\begin{array}{c}\text { Bulk density } \\
\text { (g/ml) }\end{array}$} & \multicolumn{4}{|c|}{ Nutrients (g/100g) } & \multicolumn{2}{|c|}{ Minerals (mg) } \\
\hline & & & & & & Protein & Fat & CHO & $\begin{array}{r}\text { Energy } \\
\text { (Kcal) }\end{array}$ & $\begin{array}{c}\text { Calciu } \\
\text { m }\end{array}$ & Iron \\
\hline 1. & Papadi & $\begin{array}{l}1 \text { packet(4 } \\
\text { pieces) }\end{array}$ & 1 & 7.28 & 0.07 & 0.62 & 0.99 & 4.74 & 30 & 0.29 & 0.05 \\
\hline 2. & Kodbale & 4 piece & 1 & 9.56 & 0.33 & 0.82 & 1.84 & 6.29 & 45 & 0.39 & 0.14 \\
\hline 3. & Ghate & 1 packet & 2 & 8.65 & 0.28 & 0.67 & 1.41 & 5.53 & 37 & 0.30 & 0.20 \\
\hline 4. & Sevchakli & 1 piece & 1 & 4.29 & 0.46 & 0.27 & 0.35 & 3.06 & 16 & 0.21 & 0.09 \\
\hline 5. & Chakli & 1 piece & 1 & 7.01 & 0.45 & 0.17 & 1.67 & 4.56 & 34 & 0.31 & 0.15 \\
\hline 6. & Burfi & 1 piece & 1 & 8.41 & 1.26 & 0.46 & 0.94 & 6.59 & 37 & 0.43 & 0.41 \\
\hline 7. & Mysorepak & 1 piece & 1 & 10.09 & 0.83 & 0.93 & 1.58 & 7.02 & 46 & 0.45 & 0.24 \\
\hline 8. & Milk pedha & 1 piece & 2 & 5.60 & 1.32 & 0.85 & 1.42 & 3.16 & 29 & 0.76 & 0.23 \\
\hline 9. & Benne biscuit & 1 piece & 1 & 9.00 & 0.74 & 0.68 & 2.39 & 5.36 & 46 & 0.30 & 0.36 \\
\hline 10. & Rasgulla & 2 piece & 1 & 11.16 & 0.86 & 0.14 & 0.57 & 8.86 & 41 & 0.50 & 0.26 \\
\hline
\end{tabular}


Plate.1 Selected commercially available unbranded cereal based snacks

Savory snacks

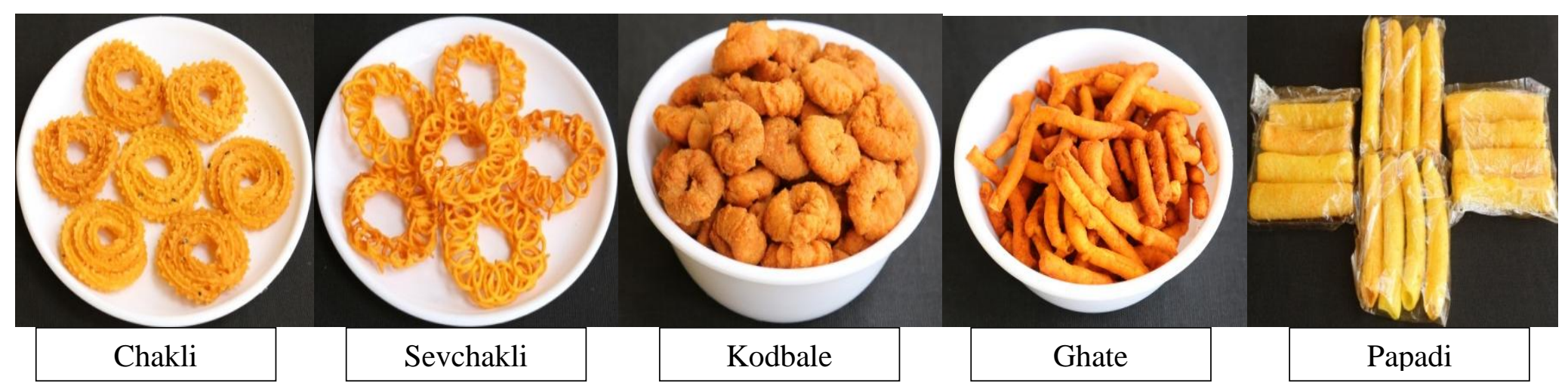

Sweet snacks

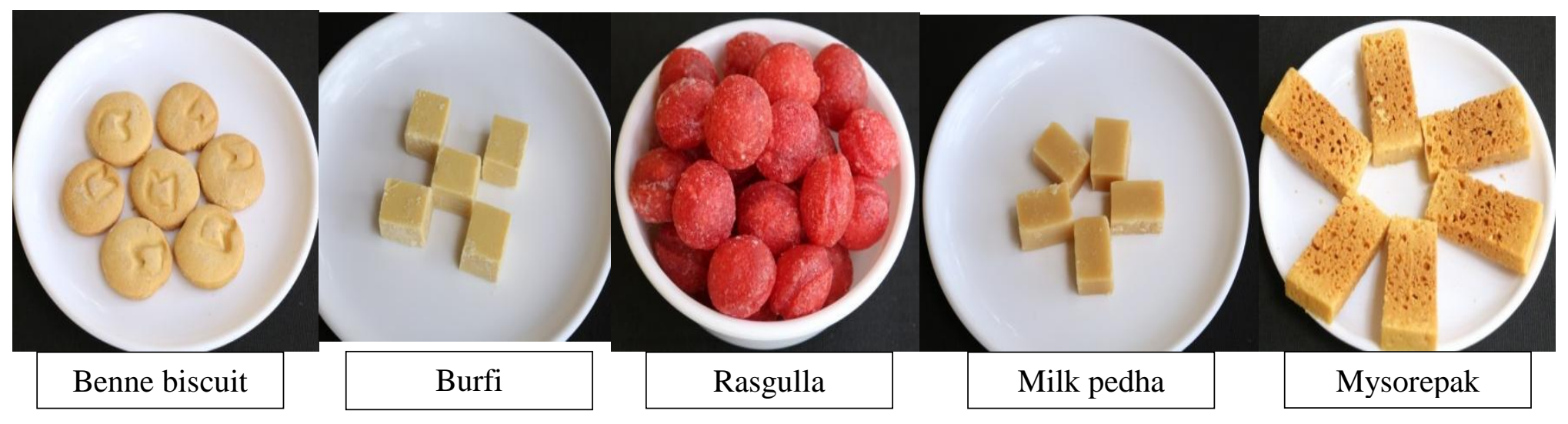


The per rupee availability of nutrients of commercially available snacks is presented in (Table 4). Among the snacks mysorepak, milk pedha, benne biscuit, and kodbale were providing good amount of nutrients like protein, fat, calcium and iron compared to other snacks. Use of pulse flour or milk based ingredient must have improved the nutrient content of snacks. Though these commercial snacks are available at one rupee and have greater market potential and acceptability by school children, but not providing adequate quantity of protein, calcium and iron to meet the $1 / 4^{\text {th }}$ requirement of the day. Per rupee these snacks are meeting only 0.02 to $0.11 \%$, 0.21 to $0.76 \%$ and 0.01 to $0.03 \%$ of recommended protein, and calcium and iron requirement of school children. Whereas, snacks are found to be rich in fat content (3.5 to $18.4 \%)$ and energy (4.1 $11.5 \%)$ values they are contributing greater percent than the $1 / 4^{\text {th }}$ of day's requirement. Snacks are lacking in micro nutrient content but, they are more calories dense and contain high fat.

Singsonet al., 2014 reported a wide variation in the fat and moisture content of commercially available chakli and also wide variation in addition of ingredients. Chakli prepared from $100 \%$ basan flour was provided $4.3 \mathrm{~g}$ of protein, $7.97 \mathrm{~g}$ of ash (Ali et al., 2017). Papadi prepared from corn and Bengal gram flour had greater values of protein $(11.24 \mathrm{~g})$ and ash $(6.09 \mathrm{~g})$ content (Reddy et al., 2014).

The nutrient values were higher in burfi prepared with Bengal gram flour as compared to the results of the present study (Bhama and Sadana, 2002). Rasgulla is a popular sweet meat prepared from channa. It contains high amount of protein, fat, vitamins and minerals (Gurveer and Goswami, 2017). Texture of rasgulla is an important parameter to acceptability and quality of rasgulla. However, commercially designed rasgullas at cheaper price for school children were made from refined wheat flour. Similarly, milk pedha was prepared from refined wheat flour and skim milk powder. Refined wheat flour fulfills the rheological properties of the snacks because of gluten content. Commercially available benne biscuits were also found nutritionally inferior to the results reported by Kumar et al., (2015) and Norhayati et al., (2015).

Scientific studies have also shown that the nutritional quality of snacks can be improved by use of composite flour. Incorporation of local cereals like little millet in chakli and kodbale has improved the nutrient composition without much change in organoleptic and textural characteristics (Ravindra et al., 2016). Reddy et al., (2014) reported the higher protein, crude fiber content and energy of extruded snacks prepared with composite flours (Bengal gram flour, corn and starch) compared to the commercial snack observed in the present study. Geetha et al., (2014) also reported higher protein content $(11.52 \mathrm{~g})$ in extrudates prepared with kodo millet and chickpea. Replacement of Bengal gram flour with millet flour in preparation of burfi had increased the nutrient content by three-fold (Bisht and Srivastava, 2013). Kumar et al., 2015 reported that, addition of foxtail millet and finger millet with refined flour had improved the protein and ash content of biscuits compared to the control (9.65 and 2.56g respectively). Naik et al., 2015 reported that the addition of pulse flour has improved the protein, crude fiber, calcium and iron content of biscuits.

From the study it was observed that commercial snacks are not providing adequate nutrients required by the school children. These snacks are generally prepared from the bulk flour supplied from the milling industry. In milling industry the main objective is to 
separate the endosperm from germ and bran. And further endosperm is gradually ground into several milling streams of flours. So the flour extraction rate indicates the whole meal flour. White flour is generated when the extraction rate is 75 or less. This flour possesses good rheological properties but, it lacks essential micro nutrients, because of non-contamination of bran (Aprodu et al., 2010; Fistes et al., 2013).

The snacks prepared from refined flour are further made more attractive and tasty with addition food additives to improve the aesthetic quality of snacks. Color usage has evoked the concern because they are being used excess of the statutory limit in the children snacks, which cause harmful effect on the health (Dixit et al., 2010; Okafor et al., 2016; Husain et al., 2008). Thus, these snacks are generally enriched with empty calorie ingredients like fat and sugar to improve the textural quality of snacks (Anon, 2015).

Children can identify snacks by quantity, cost and taste and make their own food selection. The present study findings suggest a need for constructive engagements with the food industry and nutritional guidelines for regulation of food products aimed at children. The bulk flour of milling industry can be enriched with incorporation of locally available staple grains in improving the nutritional quality of commercial snacks. Such nutri snacks can overcome the nutritional problems of the community

\section{References}

Ali, Z., Virginia, P., Singh, P. and Pande, M., 2017, Assessment of nutritional composition and antioxidant activity of Chakli incorporated with dehydrated Moringa oliefera and Solanum nigrum leaves. Int. J. Home Sci., 3(1): 36-38.

Anonymous, 2005, Official methods of analysis of Association of Official Analytical Chemists, 20th Edn. AOAC, Washington. D. C.

Anonymous, 2015, Addressing Consumption of Foods High in Fat, Salt and Sugar (HFSS) and Promotion of Healthy Snacks in Schools of Ministry of Women and Child Development Government of India. p. 9-10.

Aprodu, I., Banu I., Georgeta, S. and Ionescu, V., 2010, Effect of the Industrial Milling Process on the Rheological Behavior of Different Types of Wheat Flour. Scientific Study Res., 11 (4): 429 $-437$.

Batada, A., and Jacobson, M. F., 2016, Prevalence of Artificial Food Colors in Grocery Store Products Marketed to Children. Clinical pediatrics, 55(12): 1113-1119.

Bhama, S., and Sadana, B. K., 2002, Standardisation and Nutritional Evaluation of Products Prepared from Bengal Gram Flour. J. Hum. Ecol., 13(6): 475-476.

Bisht, A.T., and Srivastava, S., 2013, Efficacy of Millets in the Development of Low Glycemic Index Sweets for Diabetics. Malnutrition J. Nutr., 19(5): 215-222.

Dixit, S., Purshottam, S. K., Gupta, S. K., Khanna, S. K. and Das, M., 2010, Usage pattern and exposure assessment of food Colors in different age groups of consumers in the State of Uttar Pradesh, India.

Fellows, P., 2002, Food processing tehnology. Pp. 203.

Fistes, A., Rakic, D. and Aleksandar, T., 2013. The function for estimating the separation efficiency of the wheat flour milling process. J. Food Sci. Technol., 50(3): 609-614.

Food Additives and Contaminants, 27(2): 181-189.

Geetha, R., Mishra, H. N. and Srivastav, P. P., 2014, Twin screw extrusion of kodo 
millet-chickpea blend: process parameter optimization, physicochemical and functional properties. $J$. Food Sci. Technol., 51(11): 3144-3153.

Gurveer, K., and Goswami, T.K., 2017Rasgulla: A Review. Dairy and Veternary Sci. J., 2(3): 001 to 003. http://www.cry.org/statistics-on-children http://www.eatouteatwell.com/snacks-arethey-your-fourth-meal http:??www.fbnews.com/Interview/Snackfood-industry-in-India-is-competetiveevoving 40023

Husain, A., Sawaya, A., Al-Omai, A., AlZenki, S., Al-Amiri, H. and Ahmed, N. M., 2008, Estimates of dietary exposure of children to artificial food Colors in Kuwait. Food Additives Contaminants, 23(3): 245-251.

Kumar, P., Mascih, D. and Sonakar, C., 2015, Development and Quality Evaluation of Cookies Incorporated by Millets \& Cardamom Powder. Int. J. Sci. Technol., 3(8):107-112.

Lythgoe, A., Roberts, C., Madden, A. M. and Rennie, K. L., 2013. Marketing foods to children: a comparison of nutrient content between children's and nonchildren's products. Public Health Nutrition, 16(12), 2221-2230.

Norhayati, M. K., Fairulnizal, M. N., Zaiton, A., Wan Syuriahti, S. W.Z., Aswir, A. L., Ang, J. L., MohdNaeem, M. N., Suraiami, M., MohdAzerulazree and Vimala, B., 2015, Nutritional Composition of Selected Commercial Biscuits in Malaysia. Sains Malaysiana., 44(4): 581-591.
Okafor, N. S., Obonga, W., Ezeokonknow, A. M., Nurudeen, J., Orovwigh, U. and Abhiabuike, J., 2016, Assessment of the Health implications of Synthetic and Natural Food Colorants - A Critical Review. UK J. Pharmaceutical Bio Sci., 4(4):01-11.

Ravindra, U., Madhu Prasad, V.L. and Nagaraju, 2016, Value added products from little millet (Panicummiliare) and their acceptability. J. Int. Academic Res. For Multidisciplinary, 4(3): 286-292.

Reddy, K., M., Aparna, K. N., Lakshmi Devi, Krishnaiah, N., Charanjit, K. and Nagamalleswari, Y, 2014, Development of extruded Ready-To-Eat (RTE) snacks using corn, black gram, roots and tuber flour blends. J. Food Sci. Technol., 51(9):1929-1937.

Singson, H., Sharda, G. S. and Yenagi, N. B., 2014, Documentation of chakli recipes and evaluation of commercial chakli for physico-chemical and sensory attributes. Karnataka J. Agric. Sci., 27 (2): (208-212).

Surekha, N., Naik, R., Mythri, S. and Rohini D., 2013, Barnyard Millet (Echinochloa Frumentacea Link) Cookies: Development, Value Addition, Consumer Acceptability, Nutritional and Shelf Life Evaluation. $J$. Environmental Sci., 7(3): 2319-240.

Uma, L.A., Sharada, G. S., Basarkar, P. W., Meera Rao, 1997, Composition of selected street foods sold in Dharwad city. Karnataka J. Agric. Sci., 10(2): 446-450.

\section{How to cite this article:}

Akkavva Wadakappanavar, S. and Nirmala B. Yenagi. 2017. Nutritional Quality of Commercially Available Unbranded Cereal Snacks Consumed by School Children. Int.J.Curr.Microbiol.App.Sci. 6(9): 1272-1281. doi: https://doi.org/10.20546/ijcmas.2017.609.153 